\title{
Environmental factors governing the distribution of the bottlenose (Tursiops truncatus) and the spotted dolphin (Stenella attenuata) in Golfo Dulce, South Pacific, off Costa Rica*
}

\author{
Priscilla Cubero-Pardo ${ }^{1}$ \\ ${ }^{1}$ Sistema de Estudios de Posgrado, Universidad de Costa Rica, Costa Rica \\ Current address: Charles Darwin Foundation, Galápagos, Ecuador
}

\begin{abstract}
This study, conducted from June 1996 to July 1997, was directed at determining the abiotic environmental factors governing the distribution of the bottlenose dolphin (Tursiops truncatus) and the pan-tropical spotted dolphin (Stenella attenuata) in Golfo Dulce. The spotted dolphin was associated with significantly deeper zones (t-test $=-9.761$; $\mathrm{p}<0.001, \mathrm{n}=202)$ and with higher salinity $(\mathrm{t}-\mathrm{test}=-3.538 ; \mathrm{p}=0.001 ; \mathrm{n}=202)$ than the bottlenose dolphin. The combination of environmental variables in the distribution areas of each species in Golfo Dulce was different, both spatially ( $F$ $=9.724, \mathrm{df}=12 ; \mathrm{p}<0.001)$ and seasonally $(\mathrm{F}=9.735 ; \mathrm{df}=12 ; \mathrm{p}<0.001)$. Of all the environmental variables considered, Multiple Discriminant Analysis showed depth to be the main factor differenciating the distribution areas of the two species. The relationship between group size in each species, depth, and the location of their distribution areas in relation to the shore were analyzed and evidence regarding these aspects and variations in foraging strategies and prey composition was proposed to explain the differences found in their spatial distributions. Seasonal variations in salinity in the distribution areas and their inverse relationship with the time of the year were analyzed in relation to their possible combined effects on prey composition during different seasons in order to explain the seasonal variations in distribution patterns.
\end{abstract}

Key words: cetaceans, environmental factors, distribution patterns, bottlenose dolphin, spotted dolphin, Costa Rica.

\section{Factores ambientales que gobiernan la distribución del delfín bufeo (Tursiops truncatus) y del delfín manchado (Stenella attenuata) en el Golfo Dulce, Pacífico sur de Costa Rica*}

\begin{abstract}
RESUMEN. Este estudio, efectuado de junio 1996 a julio 1997, fue dirigido a determiner factores ambientales abióticos que regulan la distribución del delfín bufeo (Tursiops truncatus) y el delfín manchado (Stenella attenuata) en el Golfo Dulce. El delfín manchado estuvo asociado a zonas significativamente más profundas ( $\mathrm{t}$-test $=-9,761 ; \mathrm{p}<0,001 ; \mathrm{n}=202$ ) y con mayor salinidad ( $t$-test $=-3,538 ; p=0,001, n=202$ ), comparadas con el delfín bufeo. La combinación de variables ambientales en las áreas de distribución de cada especie en el Golfo Dulce fue diferente tanto a nivel espacial ( $\mathrm{F}=9,724$; $\mathrm{df}=12 ; \mathrm{p}<0,001)$ como estacional $(\mathrm{F}=9,735 ; \mathrm{df}=12 ; \mathrm{p}<0,001)$. Entre todas las variables ambientales consideradas, el Análisis Múltiple Discriminante (MDA) reveló la profundidad como el factor con mayor diferencia entre las áreas de distribución de las dos especies. Se analizó la relación entre el tamaño de grupo en cada especie, la profundidad y la ubicación de sus áreas de distribución respecto a la costa y fue propuesta evidencia entre esos aspectos y variaciones en estrategias de forrageo y composición de presas entre ambas especies, a fin de explicar las diferencias existentes a nivel de distribución espacial. Las variaciones estacionales en la salinidad de las áreas de distribución y su relación inversa con la época del año fueron analizadas en función de sus posibles efectos combinados sobre la composición de las presas en las épocas del año, a fin de explicar las variaciones en los patrones de distribución a nivel estacional.
\end{abstract}

Palabras clave: cetáceos, factores ambientales, patrones de distribución, delfín bufeo, delfín manchado, Costa Rica.

Corresponding author: Priscilla Cubero-Pardo (pcubero@fcdarwin.org.ec)

* This work was presented at the XXV Congreso de Ciencias del Mar de Chile and the XI Congreso Latinoamericano de Ciencias del Mar (COLACMAR), in Viña del Mar, 16-20 May 2005. 


\section{INTRODUCTION}

The spatial and temporal distribution of cetaceans is influenced by a series of environmental factors such as physical, chemical, and climatological variables; biotic factors such as competition and predation; and anthropogenic factors such as fishing activities and boat traffic, amongst others (Au et al., 1979; Jefferson et al., 1993; McLeod et al., 2004). Interactions between these different aspects vary according to the geographical area involved (Jefferson et al., 1993; T.I.O., 1995). Specifically, variations in temperature and salinity of different water masses have a great influence on the distribution of different species (Dohl et al., 1986; Evans, 1987; Baumgartner \& Mate, 2005).

In the Eastern Tropical Pacific (ETP), differences in temperature of at least five degrees centigrade and in salinity of two or more units allow the distinction of two dolphin communities (Au et al., 1979). Kenney (1990) determined that inshore and offshore distribution areas of the bottlenose dolphin vary significantly in surface water temperature values, although not in depth values. In the gulf of Mexico, bottlenose dolphins from both the shallow continental shelf and just seaward of the shelf break seemed to prefer regions with high surface temperature variability, suggesting an association with ocean fronts (Baumgartner et al., 2001).

Other studies have found variations related to distance from shore (Blaylock \& Austin, 1982) and depth (Blaylock \& Austin, 1982; Davis et al., 1995) when comparing two species sharing the same geographical area. Off the northeastern United States, the bottlenose dolphin seems to prefer significantly shallower zones than the spotted dolphin (Kenney, 1990). There is little information about this matter in coastal areas of the ETP.

In general terms, the bottlenose dolphin is mostly distributed in coastal areas, whereas the spotted dolphin prefers deep waters (Jefferson et al., 1993; Sylvestre, 1993). Based on those general tendencies and on previous results found by Acevedo-Gutiérrez \& Buckhart (1998) for the two dolphin species in Golfo Dulce, different spatial distribution patterns were predicted for the two species, with a higher probability of finding the bottlenose dolphin close to shore.

Higher proximity to shore in this species was expected to be associated with shallower areas and with lower salinity and temperature values resulting from the stronger influence of cool and fresh river waters. Swell and wind conditions in the distribution areas of the bottlenose dolphin were expected to be lower. No differences were expected in terms of cloud cover and wind speed between the distribution areas of the two species.

The clearly different behavioral patterns observed for the two dolphin species in Golfo Dulce are suggested to be a strategy to avoid competition (Cubero-Pardo, 1998a, 1998b). Separate distribution areas are expected as part of those strategies.

The objective of this study was to determine the physical environmental variables governing the spatial and seasonal distribution patterns of the bottlenose (Tursiops truncatus) and pan-tropical spotted (Stenella attenuata) dolphins in Golfo Dulce.

\section{MATERIALS AND METHODS}

Golfo Dulce is located in the South Pacific off Costa Rica around $08^{\circ} 30^{\prime} \mathrm{N}$ and $83^{\circ} 16^{\prime} \mathrm{W}$ (Fig. 1). It covers an area of $750 \mathrm{~km}^{2}$ with a minimum distance of 10 $\mathrm{km}$ in the inner part and a maximum of $25 \mathrm{~km}$ close to the mouth. It is defined as a fjord-like embayment due to its particular features, with deep slopes and a maximum depth of $210 \mathrm{~m}$ in its inner part (Hebblen $e t$ al., 1996). The influence of oceanic waters is limited due to the presence of a sill close to the mouth of the embayment.

This gulf, is characterized by two water masses that vary significantly in physical and chemical composition (Hartmann, 1994). The strong halocline located between 40 and $60 \mathrm{~m}$ depth acts as a barrier that limits the mixing of shallow and deeper waters. Besides, there is a weak stratification along the water column, except at the surface levels, that also limits mixing processes in the deeper water (Richards $e t$ al., 1971).

Water circulation is reduced due to the topography of the gulf, which is separated from the open ocean by the mountains of the Osa Peninsula. Circulation is defined by the tides (Hartmann, 1994) even though, apparently, the local wind system also has a partial influence on this aspect (Wolff \& Vargas, 1994). Circulation is similar to systems at high latitudes and makes Golfo Dulce one of only four estuaries of this kind in the tropics, similar to European fjords (Richards et al., 1971).

The study area was covered using a $5 \mathrm{~m}$ fiber glass boat and a $25 \mathrm{hp}$ outboard motor, following predefined transects (Fig. 1). These transects were 


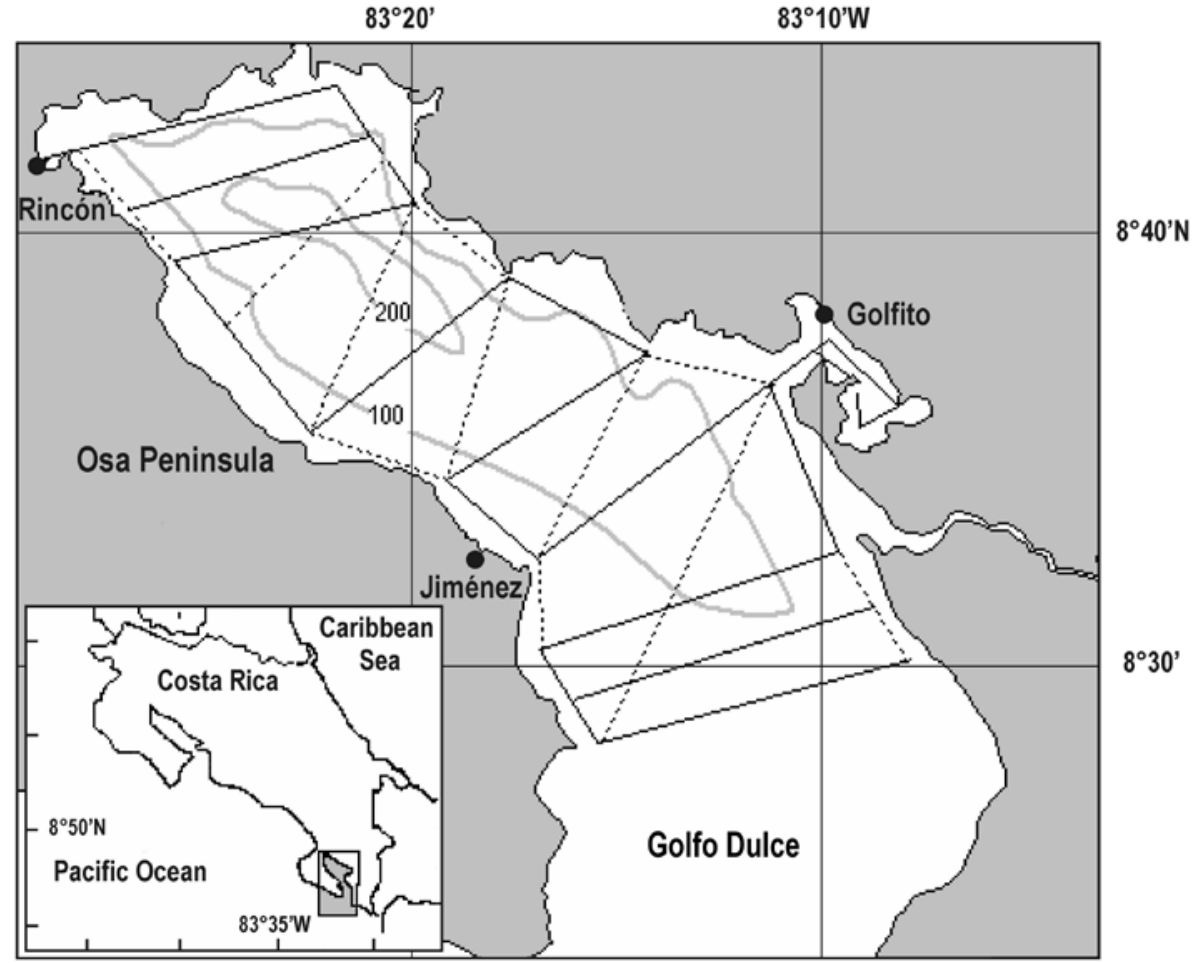

Figure 1. Golfo Dulce's location in Costa Rica.

used as a systematic guide until a group of dolphins was seen. Observations were made with the naked eye and the boat was stopped when dolphins were found. If it was necessary to move, this was done parallel to the movement of the animals and at a minimum distance of $50 \mathrm{~m}$ (except when they approached spontaneously). When a group was lost, coverage continued along of the transect. Each sampling day lasted 4 to $10 \mathrm{~h}$, depending on weather conditions. During the 12-month study period, eight days of each month were dedicated to covering the study area. Both the bottlenose and the pan-tropical spotted dolphins are distributed along the Pacific coast of Costa Rica. The former is also distributed along Puerto Rico's Caribbean coast. Golfo Dulce, however, has populations of both species that are considered to be genetically isolated (bottlenose) and semi-isolated (spotted) because their distribution ranges are limited to Golfo Dulce (bottlenose) or, when extending to the open ocean (spotted), remain near the gulf's mouth (A. Acevedo-Gutiérrez, pers. comm.).

The group location was determined using a Global Position System (GPS). Geographic coordinates obtained with this system were converted to metric coordinates using the program Convert (by Marlon
Molina, Geography School, University of Costa Rica) in order to include them in a geographic information system.

Abiotic environmental factors included surface water temperature $\left({ }^{\circ} \mathrm{C}\right)$ measured with a digital thermometer, salinity measured with a refractometer, and depth (m) according to a bathymetric map. Distance from shore was estimated according to a known value given by the GPS using previously programmed reference points. The percentage of cloud cover, swell, and wind conditions according to the Beaufort scale were estimated. Environmental variables were recorded at the end of each hour when covering transects and at the beginning of each sighting.

A group was defined as any number of dolphins observed in apparent association, moving in the same direction and often, but not always, involved in the same activity (Shane, 1990).

\section{Statistical analysis}

Comparisons were made between species in relation to each environmental variable using t-Student test. Comparisons among seasons were made using factorial ANOVAs. The year was divided into three 
climatic periods based on Acevedo-Gutiérrez \& Buckhart (1998): the dry season (January-April; DS), beginning rainy season (May-August; BRS), and end of rainy season (September-December; ERS).

Because the distribution of each dolphin species was expected to be related to particular interactions of environmental conditions on both spatial and temporal levels, Multiple Discriminant Analysis (MDA) was used, considering two a priori grouping categories: 1) records of bottlenose and spotted dolphin sightings (Sp 1 and Sp 2, respectively), and records with no dolphin sightings ( $\mathrm{Sp} 0)$, in terms of spatial characterization; and 2) the three seasons of the year for each species separately, in terms of seasonal analysis.

\section{RESULTS}

A total of 91 surveys were conducted during a 12 month period (July 1996 to June 1997). Of the 489 hours invested in the study, $114 \mathrm{~h}$ (23.3\% of the time) corresponded to sightings (total sightings $=140$ ). The bottlenose dolphin was sighted 123 times for a total of $91.5 \mathrm{~h}$, and the spotted dolphin 17 times for a total of $22.7 \mathrm{~h}$. Environmental conditions were measured every hour whether there were dolphins of any species present or not. Environmental measurements were made 171 times in the presence of bottlenose dolphins, 31 times in the presence of spotted dolphins, and 324 times with no dolphins present. The collection of environmental variables every $60 \mathrm{~min}$ resulted in a higher sample size than the total number of sightings. There was an average sampling period of $5.4 \mathrm{~h}$ per day. Sightings considered for analysis ranged from $15 \mathrm{~min}$ to $5 \mathrm{~h}$ and involved only one group at a time. Group size was between 2 to 7 individuals for the bottlenose dolphin, and from 50 to 300 individuals for the spoted dolphin. The gulf was not covered completely, but up to an imaginary line between Río Coto (SE) and Punta Tigrito (SW) (Fig. 1).

\section{Spatial analysis}

General distribution: within the sampled area, the two species were never seen together and spatial overlap seemed to be minimal. Each species occupied clearly different regions (Fig. 2). The spotted dolphin was found at significantly greater distances from the shore compared to the bottlenose dolphin (t-test $=-9.255 ; \mathrm{p}<0.001 ; \mathrm{n}=202)$. The bottlenose dolphin tended to be located between 20 and $6,000 \mathrm{~m}$ from the shore $(x=1,203.20$; S.D. $=1,433.0 \mathrm{~m} ; \mathrm{n}=$ 171), whereas the spotted dolphin was usually found between 400 and 7,000 $\mathrm{m}$ from shore $(\mathrm{x}=3,843.50$; S.D. $=1,612.6 \mathrm{~m} ; \mathrm{n}=31$ ).

The spotted dolphin was associated with deeper areas $(\mathrm{t}=-9.761 ; \mathrm{p}<0.001 ; \mathrm{n}=202)$ and higher salinities (t-test $=-3.538 ; \mathrm{p}=0.001 ; \mathrm{n}=202)$ than the bottlenose dolphin. There were no significant differences in terms of surface water temperature in the distribution areas of the two species (t-test $=$ $-0.635 ; \mathrm{p}=0.526 ; \mathrm{n}=202$ ).

According to the mode, there was no wind or swell during most of the sightings of the two species and the Beaufort scale reached minimum values of 1 or 2 (bottlenose and spotted, respectively). However, average cloud cover was higher when the spotted dolphin was found. The mode during sightings of this species was $50 \%$, as compared to $80 \%$ for the bottlenose dolphin. There were no significant statistical differences for these factors between the two species. Arithmetic means for each environmental variable are shown in Table 1.

Interactions between environmental variables in the distribution areas, i.e., comparing environmental conditions in areas where the bottlenose dolphin $(\mathrm{n}=$ $171)$, the spotted dolphin $(\mathrm{n}=31)$, and no dolphins ( $\mathrm{n}$ $=324$ ) were sighted, revealed less differences in the environmental conditions between bottlenose areas and no-sighting zones than between spotted areas and no-sighting zones. Besides, conditions associated with distribution areas for the two species showed higher differences among themselves than compared to zones with no sightings (F Wilks MDA $=9.724$; df $=12 ; \mathrm{p}<0.001 ; \mathrm{n}=526)$. Of all the environmental variables together, depth, salinity, and distance from shore - in that order - showed the greatest differences between the distribution areas of the two species in Golfo Dulce (F-to-remove MDA; depth = 9.93; salinity $=8.01 ;$ df shore $=4.35$ ).

\section{Seasonal analysis}

In seasonal terms, distance from shore was the most similar between the two species at the beginning of the DS (F ANOVA $=7.142 ; \mathrm{p}=0.001 ; \mathrm{n}=202$ ) (Fig. 3). Seasonal variations for this factor were significant in the case of the bottlenose (F ANOVA $=0.1492 ; \mathrm{p}<0.001 ; \mathrm{n}=171)$ and between species $(\mathrm{F}$ ANOVA $=0.823 ; \mathrm{p}=0.004 ; \mathrm{n}=202)$, but not for the spotted dolphin. 


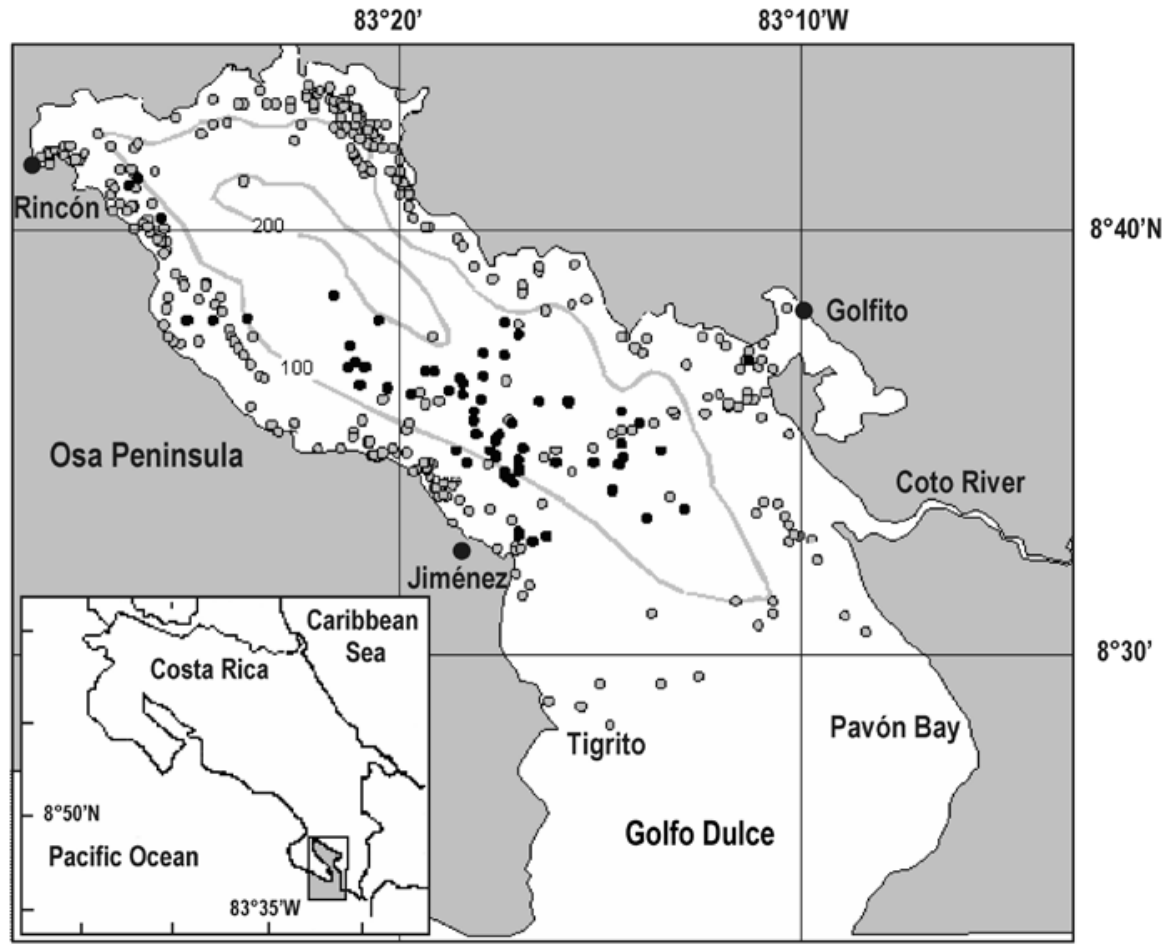

Figure 2. Distribution areas of the bottlenose (grey points) and the spotted dolphin (black points) in Golfo Dulce. (July 1996-June 1997).

Table 1. Aritmetic mean of annual environmental variables during bottlenose and spotted dolphin sightings in Golfo Dulce, July 1996-June 1997.

\begin{tabular}{lcccccc}
\hline & \multicolumn{3}{c}{ Bottlenose dolphin $(\mathbf{n}=\mathbf{1 7 1})$} & \multicolumn{2}{c}{ Spotted dolphin $(\mathbf{n}=\mathbf{3 1})$} \\
\cline { 2 - 6 } & Interval* & $\begin{array}{c}\text { Aritmetic } \\
\text { mean }\end{array}$ & $\begin{array}{c}\text { Standard } \\
\text { deviation }\end{array}$ & Interval & $\begin{array}{c}\text { Aritmetic } \\
\text { mean }\end{array}$ & $\begin{array}{c}\text { Standard } \\
\text { deviation }\end{array}$ \\
\hline Depth $(\mathrm{m})$ & $1-110$ & 34.2 & \pm 31.9 & $17-200$ & 92.7 & \pm 22.3 \\
Salinity & $0-35$ & 25.8 & \pm 6.96 & $27-34.5$ & 30.1 & \pm 1.98 \\
Temperature $\left({ }^{\circ} \mathrm{C}\right)$ & - & 29.48 & \pm 1.51 & - & 29.66 & \pm 1.06 \\
Wind speed $\left(\mathrm{km}+\mathrm{h}^{-1}\right)$ & - & 2.8 & \pm 3.6 & - & 4.2 & \pm 4.3 \\
Cloud cover $(\%)$ & - & 36.24 & \pm 27.50 & - & 63.29 & \pm 29.03 \\
Swell $(\mathrm{m})$ & - & 0.1 & \pm 0.2 & - & 0.1 & \pm 0.2 \\
\hline
\end{tabular}

* Only statistically significant variables are considered

The same results were found in terms of depth, as average values for this variable were closer among the two species at the onset of the rainy season $(\mathrm{F}$ ANOVA $=3.778 ; \mathrm{p}=0.025 ; \mathrm{n}=202$ ). Seasonal differences were significant only for the bottlenose dolphin $(\mathrm{F}=12.952 ; \mathrm{p}<0.001 ; \mathrm{n}=171)$.

Average temperature $(\mathrm{F}$ ANOVA $=11.515 ; \mathrm{p}<$ $0.001 ; \mathrm{n}=202)$ and salinity $(\mathrm{F}$ ANOVA $=6.102 ; \mathrm{p}$
$=0.003 ; \mathrm{n}=202)$ were higher during the DS $(\mathrm{x}=$ 29.992; S.D. $=0.170^{\circ} \mathrm{C}$ and $\mathrm{x}=29.308$; S.D. $=0.745$ ppm, respectively), with a decrease in the BRS (x = 29.803; S.D. $=0.284{ }^{\circ} \mathrm{C}$ and $\mathrm{x}=28.309$; S.D. $=$ $1.244 \mathrm{ppm})$ and an even greater decrease in the ERS $\left(\mathrm{x}=28.338\right.$; S.D. $=0.290^{\circ} \mathrm{C}$ and $\mathrm{x}=24.172$; S.D. $=1.271 \mathrm{ppm})$. There were no significant differences when the three seasons were compared between the two species. 


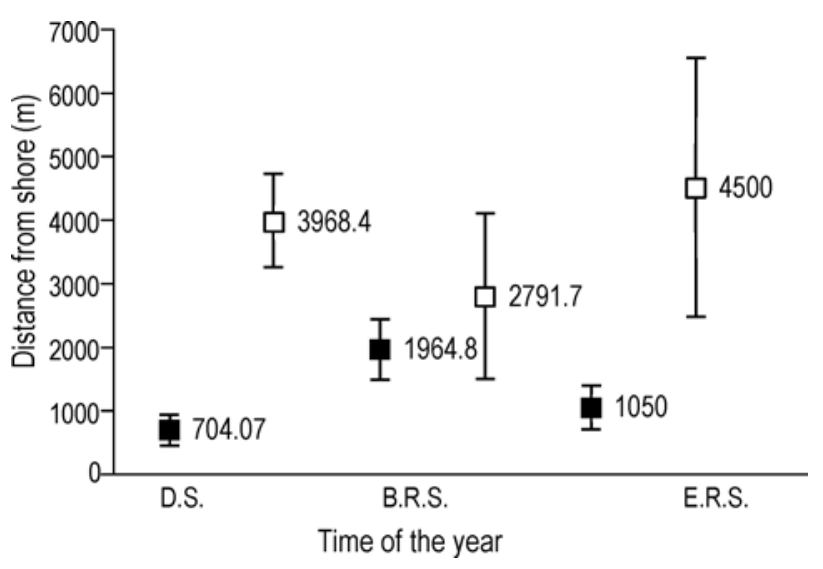

Figure 3. Seasonal aritmetic average of distance from shore for the bottlenose dolphin (black square) and the spotted dolphin (white square) in Golfo Dulce, with trust limits of 95\%. (DS: dry season; BRS: beginning of rainy season; ERS: end of rainy season), July 1996-June 1997.

Although cloud cover increased significantly from the dry season to the end of the rainy season $(\mathrm{F}$ ANOVA $=10.213 ; \mathrm{p}<0.001 ; \mathrm{n}=198)$, there were no significant differences in the conditions of cloud cover during the presence of the two species throughout the three seasons of the year. There were no important changes in swell or Beaufort scale under any circumstances.

The distribution areas of both the bottlenose $(\mathrm{F}$ Wilks MDA $=9.735 ; \mathrm{df}=12 ; \mathrm{p}<0.001, \mathrm{n}=171)$ and the spotted dolphin (F Wilks MDA $=3.863 ; \mathrm{df}=$ $12 ; \mathrm{p}=0.0004 ; \mathrm{n}=31$ ) were associated with stronger changes in environmental conditions from the BRS to the ERS than from the DS to the BRS. For the bottlenose dolphin, the greatest seasonal variations in environmental conditions were related to salinity and temperature and, to a lesser degree, to distance from shore and depth, in that order (F-to-remove MDA, salinity $=13.93 ;$ temperature $=11.83 ;$ df shore $=$ 7.48 ; depth $=6.83$ ). In the case of the spotted dolphin, seasonal variations in environmental conditions were especially related to wind speed, salinity, and distance from shore, respectively (F-to-remove MDA, wspeed $=3.68$; salinity $=2.39$; df shore $=1.92$ ).

\section{DISCUSSION}

As expected, a complete differentiation between distribution areas was found, as the two species were never seen together (Fig. 2). In spite of the changes in distribution patterns between seasons (Cubero-Pardo, 1998b), no overlap in time was evident at any time of the year. The bottlenose dolphin clearly prefers areas close to shore, whereas the spotted dolphin prefers the central, deeper area of the gulf. Depth is, in fact, the environmental variable with the highest difference between the distribution areas of the two species, followed by distance from shore. However, both aspects are linked, as the water is deeper farther from the shore (Golfo Dulce is pod-shaped).

Even though the two species have aggregated patterns (they form groups), the spotted dolphin is characterized by a less disperse population that frequently moves in groups of 50 to 300 individuals (the whole school together), whereas the bottlenose dolphin population (estimated to be 150 individuals) is segregated into small groups of 2 to 7 animals $(\mathrm{Cu}-$ bero-Pardo, 1998b). The small groups of bottlenose dolphins can accommodate themselves in the shallow areas; however, the big groups of spotted dolphins require greater areas in three dimensions. Deeper areas of the gulf allow cohesion in big groups. Even though the bottlenose dolphin was found ocasionally in the deeper areas determined for the spotted dolphin, the latter was never found in areas as shallow as three meters, where the bottlenose dolphin was frequently found.

Additionally, the use of the wider central zone of the gulf must increase the risk of predation. The bottlenose is rarely found in the gulf's central areas. Large groups of spotted dolphins must offer higher individual protection.

On the other hand, even though no analysis of prey composition or distribution was included in this study, predictability of prey for the spotted dolphin seems to be lower. Cubero-Pardo (1998b) showed 
that feeding areas are not clearly defined for spotted dolphins and that they are usually found foraging in groups of 50 or more individuals along the central area of the gulf. On the contrary, feeding grounds for the bottlenose dolphin are associated with the river mouths in the gulf and foraging activities are developed individually or in groups not exceeding five individuals. In fact, the lower average salinity associated with the general distribution area of the bottlenose dolphin is directly related to the influence of rivers in the coastal zone. This finding was as expected.

Swell and wind conditions did not differ significantly between the distribution areas of the two species. Golfo Dulce has a relatively small surface area $\left(750 \mathrm{~km}^{2}\right)$. The findings for swell and Beaufort scale were unexpected, but none of those factors vary significantly across the gulf or between seasons.

In this study, changes in salinity were higher from the beginning of the rainy season to the end of the rainy season compared to the transititon from the dry season to the beginning of the rainy season. However, according to Cubero-Pardo (1998b), seasonal distribution patterns for the two species were more similar among rainy seasons. The bottlenose dolphins showed a more disperse distribution along the east and west coasts and did not concentrate at river mouths as they did during the dry season; besides they used areas farther from shore/deeper compared to the dry season (Fig. 3). On the contrary, during rainy seasons, the spotted dolphin was less disperse across the center of the gulf and came closer to shore.

This suggests that seasonal distribution patterns in the two species are determined by biotic factors, such as availability of feeding resources, whereas abiotic factors play a secondary role. Seasonal dispersion indexes for the two species reveal bigger groups at the beginning of the rainy season, which suggests less predictable prey. The shift of the spotted dolphin closer to shore also supports this supposition.

Seasonal differences in salinity and, in the case of the bottlenose dolphin, of temperature as a second factor, have an indirect effect on the distribution of the two dolphin species. Salinity is the result of changes in the influence of oceanic or neritic waters, according to the time of year (Wolff et al., 1996), whereas water temperature is indirectly related to changes in cloud cover. These two variables have direct effects on biological composition in the gulf, at least at the zooplanktonic level (Wolff et al., 1996).
In fact, cloud cover causes indirect effects on productivity in an inversely proportional way. Because of this, the dry season must offer higher availability of feeding resources, especially concentrated close to the river mouths. The described distribution patterns of the bottlenose dolphin during the dry season support this idea.

Minimum or null species overlap could be a strategy to avoid competition in a relatively low productive ecosystem, as is the case of Golfo Dulce (Wolff et al., 1996). A previous study conducted at the begining of the 1990s determined an almost null spatial overlap between the bottlenose and the spotted dolphin (Acevedo-Gutiérrez \& Buckhart, 1998), but the present study found an even stronger pattern.

Acevedo-Gutiérrez \& Buckhart (1998) suggested that spotted dolphins might leave Golfo Dulce at least occasionally. Cubero-Pardo (1998b) supported that idea based on the higher average traveling speed of the groups of spotted dolphins and their facility for changing direction and covering areas of many kilometers in just a few minutes. A wider home range for the spotted dolphin could also diminish competition inside the gulf.

At the same time, a wider home range is associated with bigger groups, as found for the spotted dolphins. In wider areas, bigger groups can be explained by a reduction in the relative water volume that can be monitored (Wells et al., 1990), which translates into higher protection with less effort. On the contrary, small group size is usually related to near-shore areas (Shane et al., 1986; Jefferson et al., 1993) as the shallower and less exposed coastal areas may provide higher protection against potential predators (Burger \& Gochfeld, 1992; Carwardine et al., 1998).

On the other hand, the use of the wider central area by the spotted dolphin suggests that prey predictability is lower for this species. The center of the gulf is less influenced by the rivers, which have a significant impact on productivity in areas close to shore (Wolff et al., 1996). Hard-to-predict prey is usually related to large predator groups (Pulliam \& Caraco, 1994). Besides, in Golfo Dulce, the spotted dolphin seems to feed on group prey (A. AcevedoGutiérrez, pers. comm.) and usually group prey is also associated with big predator groups (Corkeron, 1994). The spotted dolphin has been found foraging on individual prey (A. Acevedo-Gutiérrez, pers. comm.).

Low heterogeneity of environmental conditions among seasons in tropical areas has been suggested 
as the main cause limiting the existence of seasonal distribution patterns in dolphins (Reilly, 1990). In Golfo Dulce, however, changes in distribution patterns between seasons have been observed (Acevedo-Gutiérrez \& Buckhart, 1998; Cubero-Pardo, 1998b).

The coastal biomassic spectrum in Golfo Dulce demonstrates that, during the rainy seasons, planktonic communities are undeveloped and most productivity and energy use comes from small organisms. On the contrary, coastal species richness increases during the dry season, as do bigger size groups (von Wangelin \& Wolff, 1996). Seasonal distribution patterns must be defined by prey composition, distribution, and availability. A. Acevedo-Gutiérrez (pers. comm.) found preliminary seasonal variations in the types of prey consumed by each dolphin species within Golfo Dulce.

Cubero-Pardo (1998a) found significant differences in the behavioral patterns that characterize the populations of the two species. The combination of distribution and behavior determine structures in the two populations that allow them to share a relatively small and unproductive environment.

\section{CONCLUSIONS}

Golfo Dulce is a relatively small fjord-like embayment with low productivity (von Wangelin \& Wolff, 1996). Specific abiotic factors play a secondary role in defining the distribution of the two species in spatial terms, whereas biotic factors seem to be the main mechanisms at the seasonal level. Differences found under these contexts seem to be the result of strong mechanisms for avoiding competition. However, because the balance between the two populations is based on extreme patterns, it seems to be fragile.

\section{ACKNOWLEDGMENTS}

I am deeply grateful to my father, Álvaro Cubero Rodríguez + , for his great support in the development of the original research from which this publication was extracted. Thanks to the Fundación para la Investigación of the Universidad de Costa Rica, to Vicerrectoría de Investigación of the Universidad de Costa Rica, to Borda Azul Enterprise, and to the Instituto Costarricense de Pesca y Acuacultura for the economic and logistical support provided.

\section{REFERENCES}

Acevedo-Gutiérrez, A. \& S. Buckhart. 1998. Seasonal distribution of bottlenose (Tursiops truncatus) and pan-tropical spotted (Stenella attenuata) dolphins (Cetacea: Delphinidae) in Golfo Dulce, Costa Rica. Rev. Biol. Trop., 46(suppl. 6): 91101.

Au, D.W.K., W.L. Perryman \& W.F. Perrin. 1979. Dolphin distribution and the relationship to environmental features in the Eastern Tropical Pacific. Adminisrative report No. LJ-79-43 of the Southwest Fisheries Center. Nat. Mar. Fish. Serv., 25 pp.

Baumgartner, M.F. \& B.R. Mate. 2005. Summer and fall habitat of North Atlantic right whales (Eubalaena glacialis) inferred from satellite telemetry. Can. J. Fish. Aquat. Sci., 62: 527-543.

Baumgartner, M.F., K.D. Mullin, L.N. May \& T.D. Leming. 2001. Cetacean habitats in the northern Gulf of Mexico. US. Fish. Bull., 99: 219-239.

Blaylock, R.A. \& H.M. Austin. 1982. The distribution and abundance of bottlenose dolphins, Tursiops truncatus, in Virginia's southern nearshore coastal waters. Final Report to the National marine Fisheries Service, Grant No. NA-80-FA-D-0008, $14 \mathrm{pp}$.

Burger, J. \& M. Gochfeld. 1992. Effect of group size on vigilance while drinking in the coati, Nasua narica, in Costa Rica. Anim. Behav., 44: 10531057.

Carwardine, M., E. Hoyt, R.E Fordise \& P. Gill. 1998. Whales, dolphins \& porpoises. Time Life Books, Hong Kong, 288 pp.

Corkeron, P.J. 1994. Social behaviour. In: R. Harrison \& M.M. Bryden (eds.). Whales, dolphins and porpoises, Facts on File, Sydney, pp. 142-159.

Cubero-Pardo, P. 1998a. Patrones de comportamiento diurnos y estacionales de Tursiops truncatus y Stenella attenuata (Mammalia: Delphinidae) en el Golfo Dulce, Costa Rica. Rev. Biol. Trop., 46(supl. 6): 103-110.

Cubero-Pardo, P. 1998b. Distribución y patrones de actividad del bufeo (Tursiops truncatus) y el delfín manchado (Stenella attenuata) en el Golfo Dulce, en relación con variables ambientales. Tesis de Maestría. Universidad de Costa Rica, 83 pp.

Davis, R.W., G.P. Scott, B. Würsig, G.S. Farigion, W.E. Evans, L.J. Hansen, R.Banson, K.D.Mullin, T.D.Leming, N.May, B.R. Mate, J.C. Norris, T.A. Jefferson, D.E. Peake, S.K. Lynn, T.D. Sparks \& C. Schroeder. 1995. Distri- 
bution and abundance of marine mammals in the North-Central and Western Gulf of Mexico: Draft Final Report. Volume II: Technical Report. OCS Study $\mathrm{N}^{\circ}$ MMS 95-. Texas Institute of Oceanography and the National Marine Fisheries Service. U.S. Dept. of the Interior, Minerals Mgmt. Service, Gulf of Mexico OCS Region, New Orleans, 333 pp.

Dohl, T.P., M.L. Bonnell \& R.G. Ford. 1986. Distribution and abundance of common dolphin, Delphinus delphis, in the Southern California Bight: a quantitative assessment based upon aereal transect data. US. Fish. Bull., 84(2): 333-343.

Evans, P.G.H. 1987. The natural history of whales and dolphins. Chapter 5, pp. 90-118. Facts on File Publication, New York, 237 pp.

Hartmann, H.J. 1994. The Golfo Dulce marine environment: review and critical assesment. Department of Biology of La Rochelle, University of La Rochelle, Charente Maritime, 34 pp.

Hebblen, D., D. Beese \& J. Cortés. 1996. Morphology and sediment structures in Golfo Dulce, Costa Rica. Rev. Biol. Trop., 44(suppl. 3): 1-10.

Jefferson, T.A., S. Leatherwood \& M.A. Webber. 1993. Marine mammals of the world. FAO species identification guide. Rome, FAO, 320 pp.

Kenney, R.D. 1990. Bottlenose dolphins off the Northeastern United States. In: S. Leatherwood \& R. R. Reeves (eds.). The bottlenose dolphin. Academic Press, San Diego, pp. 369-386.

MacLeod, K., R. Fairbairns, A. Gill, B. Fairbairns, J. Gordon, C. Blair-Myers \& E.C.M. Parsons. 2004. Seasonal distribution of minke whales $B a$ laenoptera acutorostrata in relation to physiography and prey off the Isle of Mull, Scotland. Mar. Ecol. Prog. Ser., 277: 263 - 274.

Pulliam H.R. \& T. Caraco. 1984. Living in groups: is there an optimal group size? In: J.R. Krebs \& N.B. Davies (eds.). Behavioural ecology, an evolutionary approach. Blackwell Scientific, Oxford, pp. 122-147.

Received: 14 September 2005; Accepted: 25 June 2007
Reilly, S.B. 1990. Seasonal changes in distribution and habitat differences among dolphins in the eastern tropical Pacific. Mar. Ecol. Prog. Ser., 66: 1-11.

Richards, F.A., J.J. Anderson \& J.D. Cline. 1971. Chemical and physical observations in Golfo Dulce, an anoxic basin in the Pacific coast of Costa Rica. Limnol. Oceanogr., 16: 43-50.

Shane, S.H. 1990. Behavior and ecology of the bottlenose dolphin at Sanibel Island, Florida. In: S. Leatherwood \& R.R. Reeves (eds.) The bottlenose dolphin. Academic Press, San Diego, pp. 245265.

Shane, S.H., R.S. Wells \& B. Würsig. 1986. Ecology, behavior and social organization of the bottlenose dolphin: a review. Mar. Mamm. Sci., 2(1): 34-63.

Sylvestre, J.P. 1993. Dolphins and Porpoises; a worldwide guide. Starling Publishing, New York, $160 \mathrm{pp}$.

Texas Institute of Oceanography (T.I.O.). 1995. Distribution and abundance of marine mammals in the northern Gulf of Mexico. Rep.N ${ }^{\circ}$ 1445-ORFP95-005. Coastal and Marine Ecosystem Program: distribution and abundance of marine mammals, pp. 57-59.

Von Wangelin, M. \& M. Wolff. 1996. Comparative biomass spectra and species composition of the zooplancton communities in Golfo Dulce and Golfo de Nicoya, Pacific coast of Costa Rica. Rev. Biol. Trop., 44: 135-155.

Wells, R.S., A.B. Irvine \& M.D. Scott. 1990. The social structure of inshore odontocetes. In: L.M. Herman (ed.). Cetacean behavior: mechanisms and functions. Wiley \& Sons, New York, 463 pp.

Wolff, M. \& J.A. Vargas (eds.). 1994. R/V Victor Hensen Costa Rica Expedition 1993/1994. Cruise report of the Center for Tropical Marine Ecology (ZMT). Bremen, Germany, 109 pp.

Wolff, M., H.J. Hartmann \& V. Koch. 1996. A pilot trophic model for Golfo Dulce, a fjord-like tropical embayment, Costa Rica. Rev. Biol. Trop., 44(suppl. 3): 215-231. 
